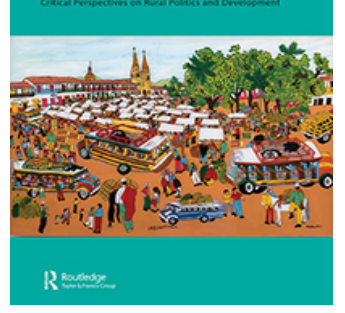

ISSN: 0306-6150 (Print) 1743-9361 (Online) Journal homepage: https://www.tandfonline.com/loi/fjps20

\title{
Recognition through reconnaissance? Using drones for counter-mapping in Indonesia
}

\author{
Irendra Radjawali, Oliver Pye \& Michael Flitner
}

To cite this article: Irendra Radjawali, Oliver Pye \& Michael Flitner (2017) Recognition through reconnaissance? Using drones for counter-mapping in Indonesia, The Journal of Peasant Studies, 44:4, 817-833, DOI: $10.1080 / 03066150.2016 .1264937$

To link to this article: https://doi.org/10.1080/03066150.2016.1264937

曲 Published online: 23 Feb 2017.

Submit your article to this journal $₫$

Џll Article views: 1244

Q View related articles $\asymp$

View Crossmark data \lceil

Citing articles: 15 View citing articles 주다. 


\title{
Recognition through reconnaissance? Using drones for counter-mapping in Indonesia
}

\author{
Irendra Radjawali, Oliver Pye and Michael Flitner
}

\begin{abstract}
Indonesia has a long history of land grabs before this term was coined, reaching from colonial occupation to cleptocratic rule. The most recent wave of enclosures across the archipelago builds on large-scale, market-oriented spatial planning. This paper shares our experience of using unmanned aerial vehicles (drones) to produce highquality community controlled maps in order to challenge some of the official spatial planning processes in West Kalimantan. Developed at first as a component of action research looking at the political ecology of the Kapuas River, the drone mapping soon developed its own dynamics and delivered quite impressive results in bolstering legal and political claims of Non-Governmental Organisations (NGOs) and Dayak communities. We argue that relatively simple and accessible drone technology has some potential for furthering the recognition of local and indigenous people and their territorial claims. Such a view, however, stands in contrast to recent debates that have highlighted the limits and even detrimental social and political effects of countermapping. Drawing on our experience with 'community drones', we compare 'traditional' and drone counter-mapping in key dimensions of production, distribution and use. This comparison helps to delimit more clearly the occasions and conditions under which drone-based counter-mapping may be a politically useful tool.
\end{abstract}

Keywords: land grabbing; drones; counter-mapping; oil palm plantations; mining; West Kalimantan

\section{Introduction}

Land grabbing has been (and is) an integral part of the state-coordinated development effort in Indonesia throughout the twentieth century and up to the present day. Over the last few decades, the country has assumed the role of resource supplier in the trade-liberalized Association of Southeast Asian Nations (ASEAN). The Indonesian state has translated this into an internal, regional division of labor with a 'plan for accelerated development' - the MP3EI (Master Plan Percepatan Pembangunan Ekonomi Indonesia) - in which different provinces are earmarked for different types of natural resource extraction and industries. In this vision, the development of West Kalimantan will be led by the palm oil, bauxite mining and timber industries (Rachman and Yanuardy 2014), industries which operate by obtaining concession permits for large areas. Due to overlapping permits, 130 percent of the total area of West Kalimantan is now covered by concessions for mining, palm oil, logging and pulp and paper plantations (Swandiri Institute 2014).

A key component of this development strategy is maps produced in the spatial planning process. Officially, spatial planning regulations has stipulated different forms of

This article was originally published with errors. This version has been corrected. Please see Erratum (https://doi.org/10.1080/03066150.2017.1362775). 
participation since the mid-1990s. Recent legislation is supposedly characterized by the following principles: (1) integrating multi-sector interests; (2) protecting public interests where communities' interests are the priority; and (3) legal assurance and justice, where spatial planning processes have to comply with laws and regulations and promote justice for all parties (Law no. 26/2007). In reality, however, permits are often handed out by government bodies at the provincial and regency level without the knowledge, let alone the consent, of the people living in the area. Government planners decide whether an area is conservation forest, production forest, or a mining area, etc. Local elites and outside investors now compete or join forces in commodifying and transforming space at an unprecedented scale (Lembaga Gemawan 2013). One expression of this dynamic in West Kalimantan is that 447,635 ha of oil palm concessions - located inside areas classified as forest - are to be 'legalized' by retrospectively changing their status from 'forest' to 'other land use' (Area Penggunaan Lain, APL; Swandiri Institute 2014).

Yet the new maps do not go unchallenged. 'Counter-mapping' indigenous and local claims to territory has a long-standing tradition in Indonesia, and in particular in Kalimantan (Peluso 1995; Pramono, Natalia and Janting 2006). In the run-up to the passing of a new Provincial Regulation on Spatial Plan Documents (RTRW) of West Kalimantan in 2015, civil society organizations created the 'Civil Society Coalition for a Just and Sustainable Spatial Plan in West Kalimantan' to influence the content of the new legislation and to challenge specific land categorizations. The commoditization of space within the spatial planning process has thus become a contested arena, a terrain on which resistance to land grabbing is unfolding.

In this broader context, the contribution discusses the potential for using unmanned aerial vehicles (drones) as a counter-mapping tool against land grabs. We draw on empirical action research conducted within a project on the political ecology of the Kapuas River in West Kalimantan between 2011 and 2015. In this project, one of the authors (IR) introduced the drone to map a bauxite mining concession that was overlapping land claimed by a local community in Tayan. Because of the high-resolution photographs produced by the drone, his action research team was able to create high-quality maps that - after several interconnected events - were later acknowledged as evidence by the Constitutional Court of Indonesia. This also contributed to the emergence of a broader movement to revise mining and oil palm plantation concessions in West Kalimantan based on the high-precision drone maps, the Eyes on the Forest Coalition (Eyes on the Forest Jaringan Kalimantan Barat 2016). The successful deployment of drones as an anti-land-grabbing device has inspired indigenous and environmental justice activists, who are now using drones in different parts of Indonesia to challenge land grabs and to back up local claims to land and forests.

This contribution starts with a brief review of the debates around counter-mapping. In particular, we look at the problematic features that have been attributed to participatory and counter-mapping efforts over the last few years by different authors with regard to their power effects. We then look at the developments in Indonesia, and sketch what we see as a window of opportunity for counter-mapping activities at the present moment.

In the second part, we concentrate on the conditions under which the drone technology was deployed successfully. We expound one example, a conflict around bauxite mining in the Tayan region, in more detail and discuss its merits. In the last section, we come back to our theoretical analysis to assess in a comparative manner the characteristics of 'traditional' and drone counter-mapping in key dimensions of production, distribution and use. This comparison helps to delimit more clearly the occasions and conditions under which drone-based counter-mapping may be a politically useful tool against land grabbing. 


\section{Counter-mapping and its critique}

The idea and practice of counter-mapping both start from the assumption that mapping is an activity deeply entangled in power relations (Harley 1988; Wood 1992). Consequently, maps themselves 'are not innocent images' (Vermeylen, Davies, and Van Der Horst 2012, 122), nor are they objective in the common understanding of the term. Rather, maps can be understood as complex social texts, highlighting, justifying and legitimizing certain social structures and relations, while hiding and silencing, or misrepresenting and manipulating, others. The positive vision of counter-mapping is therefore to correct and counter such manipulation, one-sidedness or silencing, and struggle for the recognition of differing worldviews and political as well as legal claims.

Several factors have contributed to a proliferation of 'alternative', bottom-up-driven mapping endeavors over the last quarter of a century. On the one hand, socio-technical developments have led to a much wider accessibility of personal computers, mapping software and tracking tools, like handheld Global Positioning System (GPS) units. On the other hand, a long-term trend to broaden public participation has taken root in international organizations and development agencies, driven by democratic ideals as well as by neoliberal interpretations of individual responsibility and empowerment. As a result of both developments, counter-mapping is now part of a whole range of mapping approaches under names like participatory mapping, citizen mapping, indigenous cartographies, and more. As individuals and social groups of all kinds produce their own maps, they are entering and expanding a realm of representations that was hitherto largely reserved for states and a few other powerful actors.

Unsurprisingly, with this diversification and multiplication over the years, the contours of counter-mapping have blurred. Volunteering geographical information or engaging local farmers in delimiting conservation lands is not necessarily 'contra' anything. Such activities may even reinforce existing problems and inequalities. This did not go unnoticed among scholars with a more critical perspective, and has led to three main lines of critique with regard to counter-mapping that can be roughly classified as epistemological, socio-economic and political, in the narrower sense of the term.

On the epistemological level, there are two basic arguments. The first is that the foundations and traditions of map-making that are conceived as 'modern' ('colonial', 'Western') are inherently unsuited to deal with 'non-Western' socio-spatial relations and knowledge systems. Accordingly, 'indigenous cartographies [are] ontologically, epistemologically, and axiologically different from Western cartographic practices' (Louis, Johnson, and Pramono 2012, 77) which could make it difficult, if not impossible, to reach adequate recognition across the deep cultural knowledge divides. A number of authors have criticized the underlying assumption of an unbridgeable divide between 'indigenous' and 'Western' knowledge systems on both political and historical grounds (e.g. Agrawal 1995; Li 2000). Others have argued that these divides may be of historical relevance but that new 'hybrid' forms of mapping have emerged: 'In spite of their unique worldviews, Indigenous people, academic scholars, and non-governmental organizations have collaborated in blending of cultural, political, scientific and technical systems through ethno-cartography/countermapping' (Palmer 2012, 82). By all means, a very careful 'geographic translation' is needed to counter the colonial and postcolonial dispossessions. The second concern is that the mapping process itself will change the perception and values of the communities involved (Fox et al. 2008, 204). As Nancy Peluso observed in an early paper, this may happen by way of 'freezing' certain social processes, by transforming them into stable spatial representations (Peluso 1995, 400). 
Such processes relate directly to the set of critical socio-economic arguments. One critical question is to what extent the often-marginalized actors have the necessary resources to use the mapping technologies. Two decades ago, Peluso $(1995,387)$ raised fears that the costs of mapping could be 'prohibitive for most local people, particularly in poor areas' (emphasis in original), but one might argue that basic technical solutions have become much cheaper and more widely available since then. Nevertheless, resources in a broader sense may be difficult to mobilize, including the necessary skills. Therefore, Fox et al. argue that the widespread adoption of spatial information technologies 'will disadvantage small local communities ... relative to other actors and stakeholders' (Fox et al. 2008, 207). Secondly, the mapping itself can intensify economic competition within communities as much as with 'outsiders' seeking access to land or natural resources. Pressure 'from within the community' may also grow simply as a result of the clarification of claims to exploit certain areas (Pramono et al. 2006, n.p.). Many counter-mapping efforts have an implicit orientation towards issues of property and property boundaries. Wainwright and Bryan have identified this orientation as one of the unresolvable inner contradictions or 'aporias of the cartographic-legal strategy' (Wainwright and Bryan 2009, 161).

These 'ironic effects' (Fox et al. 2008, 206) or 'unintended effects' (Wainwright and Bryan 2009, 154) become even more troublesome on the political level. Participatory and counter-mapping may change internal social dynamics, may open new avenues for co-optation and corruption, and can lead to new hierarchies (Fox et al. 2008, 208). As Parker (2006) argues, the technology of community mapping needs to be contextualized within the political fields of inclusion, transparency, and empowerment. Particularly problematic is the presumption of 'solidarity, solidity, or shared values' within a geographically defined 'community' (Parker 2006, 471). Rather, the mapping process is 'fraught with tension and marked by unacknowledged privilege' as shown by the fact that 'women's space and perceptions of place were often excluded in indigenous maps' (Parker 2006, 472-73). Accordingly, original intentions may be entirely lost or depoliticized in the process of translating political claims into technical-scientific products that are 'legible' for the state or other powerful actors (cf. Scott 1998). Hence, the underlying 'struggle for recognition' (Honneth 1996) may be compromised. As Wainwright and Bryan (2009, 161) put it, the

[S]truggle for justice may involve people unevenly ..., the struggle for unity may produce new spatial and political divisions, ... the struggle for collective lands may lead to privatization ... [and the] struggles for indigenous self-determination may increase state power.

Despite such fundamental criticism, not only do proponents of participatory and countermapping continue working to make maps, but also most critical scientists dealing with the issue still see some merits in the approach. In fact there has been some overlap between the two groups, and the practicing counter-mappers have noticed many of the limitations and inherent problems early on. A fairly common 'realist' position is to say that there is not much of an 'exit option' in this mapping world, and that villagers longing for protection of their territory and resources 'have no choice but to map' (Fox et al. 2008, 212). At the same time, there is broad agreement that mapping is not the tool to abolish deep-seated forms of power and social injustice. Neither can it overcome inequitable social relations and institutions like private property or the territorial nation state. Yet counter-mapping tools may be useful or necessary at certain moments in specific political conflicts. In this way, the debates over the power of maps and mapping processes have certainly sensitized the counter-mapping community that it is not simply about getting the 
'good' or 'correct' map, but just as much about the power dynamics in the necessary processes of collaboration. The Indonesian experience in counter-mapping provides support for this argument.

\section{Counter-mapping in Indonesia}

Indonesia has a rich history of participatory and counter-mapping activities that not only mirror the international debates, but have substantially influenced where this debate stands today. Participatory mapping first emerged in 1992 under two circumstances: (1) the spread of an international discourse on community-based natural resource management (CBNRM) as part of the broadening sustainable development agenda, and (2) the evolution of the Indonesian environmental movement from a movement against the impact of largescale development interventions into a movement to reclaim customary rights (Jaringan Kerja Pemetaan Partisipatif 2009). One of the first participatory mappings was organized by the World Wide Fund for Nature (WWF) around Long Uli Village in East Kalimantan Province, which is located on the border of what is now Kayan Mentarang National Park. In this case, participatory mapping was criticized as a method that was concerned not primarily with taking into account community perspectives, but rather with creating legitimacy for a specific programme (Jaringan Kerja Pemetaan Partisipatif 2009).

A broader counter-mapping movement developed through the 1990s as a response to two decades of industrial timber exploitation and the Indonesian government's superseding of customary forest rights through official planning and mapping efforts (Peluso 1995). It was conducted by local activists with assistance from international organizations and sometimes government agencies. Counter-mapping tended to delineate and formalize claims to forest territories and resources that certain communities or villages had traditionally managed by using sketch maps (Peluso 1995). In some cases, geographical referencing using a global positioning system (GPS) and sophisticated software were used (Sirait et al. 1994; Momberg 1994 in Peluso 1995). The aim was, 'to appropriate the state's techniques and manner of representation to bolster the legitimacy of "customary" claims to resources' (Peluso 1995, 384, emphasis in original).

From the 1990s onwards, participatory mapping has been used and developed by various organizations across Indonesia, particularly by those dealing with agricultural and forestry issues. In 1996, a workshop on community mapping in Bogor gave birth to the Community Mapping Network (Jaringan Kerja Pemetaan Partisipatif, JKPP) which connects and facilitates the participatory mapping movement (JKPP 2009). By 2009, 510 villages and/or communities had mapped their territory, involving 2.5 million ha of land, and JKPP's membership has grown to 63 organization and 35 individual members (JKPP 2009). The network has been working closely with the Alliance of Indigenous Peoples of the Archipelago (Aliansi Masyarakat Adat Nusantara, AMAN) to support AMAN's ongoing initiative on reclaiming customary areas.

A factor that facilitated the rise of participatory mapping in the early years was the high interest of international donor agencies (JKPP 2009). Flows of grant funds were the key factor in the success of participatory mapping up to the fall of Suharto's New Order regime in 1998 when the interest of donor organizations shifted towards more explicitly political and institutional aims such as establishing 'good governance'. JKPP was too late to anticipate this shift, and, with declining support, became trapped in the 'technicalities' of participatory mapping before changing direction to give more weight to social, economic, cultural and political contexts, and thus shifting their focus from 'technical mapping' to becoming an advocacy network. In particular, the network started focusing 
on spatial planning processes which were becoming the main tool of land control by the state and corporations, and in which local communities were not involved.

The counter-mapping movement was particularly strong among the Dayak groups in West Kalimantan, where 'challenging the state claims over indigenous territories' was at the 'core of their struggles' and 'hundreds of kampungs in West Kalimantan had been mapped within the framework of counter-mapping', leading to a greater cohesion between community members and to a 'revitalization of Dayak identity' (Pramono et al. 2006, n.p.[1,8]).

A decade after the critiques by Peluso (1995), the review of Pramono et al. (2006) indicated that many of the problems mentioned by Peluso continued to plague the movement, in particular the tendency of counter-mapping to create new types of power and control. By accepting state administrative units, counter-mapping can produce knowledge that can then be used by the state for land grabbing. Computer-based mapping technology 'separates the communities from map production' (Pramono et al. 2006, n.p.[10]) while the maps themselves transfer spatial knowledge to the hands of outsiders, such as NGOs and state entities. In addition, the counter-mapping movement has become obsessed with the technicalities of map production, seeing the mastery of mapping tools as an end to itself and losing sight of the political content of land rights. Perhaps most importantly, the profusion of local maps was largely unable to 'influence the political landscape at the kabupaten level, not to mention provincial and national levels' (Pramono et al. 2006, n.p.[11]). Yet along with technical possibilities, the political background conditions have changed over the subsequent decade since 2006, and today we find a situation where counter-mapping makes a forceful reappearance on the regional and national stage.

\section{A window of opportunity}

In recent years, political developments have created a window of opportunity for countermapping to have a major impact on the spatial planning process. In May 2013, through Constitutional Court Decision No. 35/PUU-X/2012, the Government of Indonesia (GoI) officially acknowledged that customary forests belonging to indigenous communities are not state forest as previously stated by the 1999 Forest Law. This was a major victory for AMAN, which had challenged the Forest Law in the courts. Following the coming into effect of the Court's decision, AMAN, JKPP and Badan Registrasi Wilaya Adat (BRWA) registered about 4.8 million ha of customary territories (data until December 2014). However, partly because of disagreements between the Ministries of Environment and Forestry and the National Agrarian Agency the principled recognition of customary forests has not yet been implemented on the ground.

A further interesting legal development has evolved around the role of villages in issues of territory and planning. A village-level movement called Gerakan Desa Membangun (GDM)/Village Development Movement emerged in 2011. In 2013, GDM and Budiman Sudjatmiko (a Member of Parliament and the ex-chair of the People Democratic Party) established an online support site for villages called Web Desa Indonesia, providing the means to connect and to consolidate villages. One of the biggest achievements of this movement is the creation of a Ministry of Village Affairs (Kementrian Pedesaan) by President Joko Widodo. Another outcome is the Village Law (No. 6/2014) that aims to strengthen the villages in terms of financial autonomy and administrative governance. This has been seen as an opportunity to sort out the messiness of village borders as villages are given a larger authority to plan their territory. So far, not even 20 percent of the approximately 74,000 Indonesian villages have been formally mapped; the rest have only informal or indicative maps of limited legal value, with concessions overlapping village land leading 
to ongoing land conflicts (Hanafi 2015). The Village Law has now given the legal backing for villages to conduct their own mapping, which is seen by various organizations as a new chance to use participatory mapping for reclaiming local territory.

The constitutional court's decision to recognize customary forests and the strengthening of village autonomy opens considerable space for counter-mapping and raise hopes that it can gain in influence and be scaled up to the national level. Together with several other NGOs (JKPP, Forest Watch Indonesia, Konsorsium Pendukung Sistem Hutan Kerakya$\tan / \mathrm{KpSHK}$ and Sawit Watch) AMAN established a body for the registration of customary territories (Badan Registrasi Wilayah Adat, BRWA) in 2010 with the aim of consolidating data and information produced by participatory mapping. The establishment of BRWA could play a larger role in consolidating customary territories and has identified as the biggest challenge to its efforts the discrepancies between government agencies and NGOs active in participatory mapping, especially over the methods used. One key problem is rooted in the need for a formal, legal recognition of the maps and methods. So far, participatory mapping hasn't been officially accepted and recognized by the Geospatial Information Body (Badan Informasi Geospasial, BIG). According to Indonesian Law No. 4/2011 regarding geospatial information, BIG is the only body which can produce official maps of Indonesia at any level. This has been a major problem for participatory mapping in Indonesia, as this means that counter-maps were not legally recognized (Hanafi 2015).

\section{Using drones for counter-mapping}

Our work with drones in West Kalimantan was part of a larger research project on 'Connecting the urban and the rural: a political ecology of the Kapuas River (Kalimantan, Indonesia)'. The project developed an action-research approach with a series of seven 'Participatory Hydro-Political Appraisals' (PHPAs) to provide a qualitative understanding of major transformations affecting the Kapuas. PHPAs were conducted in seven locations from Kapuas Hulu down to Pontianak on the issues conservation and Reducing Emissions from Deforestation and Forest Degradation (REDD), logging, palm oil, gold mining, bauxite mining, fisheries, and drinking water and sewage politics. The PHPAs took an action research approach by forming 'citizen research groups' with whom key research questions and a collection of modules including place narratives, river transects, spatial problem analysis, change objective discussions and spatial intervention analysis were developed (for more detail on this project see Pye, Radjawali and Julia 2017).

The use of drones in our action research project in 2013 and 2014 took place in the context of excitement and optimism within the counter-mapping movement. Our research project cooperated closely with the civil society coalition intervening in the spatial planning process in West Kalimantan, which was interested in the issues at the local sites and in the way we connected these conceptually to changes in the political ecology of the river as a whole (Pye, Radjawali and Julia 2017). Initially, the drones were only meant to be an additional tool to support our research with high-quality and high-resolution spatial data in areas where access was restricted by company security and police. The first author (IR) built the first drone without any previous training, using online sources and secondhand components (for more detail see Radjawali and Pye 2017). Soon, the drones set off a dynamic process in which we collaborated closely with NGOs working for a more transparent and just spatial plan. The West Kalimantan initiative then gained the attention of coalitions and networks such as AMAN, Wahana Lingkungan Hidup Indonesia (WALHI) and Publish What You Pay (PWYP) Indonesia at the national level. 
The civilian use of autonomous unmanned aerial vehicles (UAVs) has been gaining pace over the last decade, in particular for environment-related monitoring (cf. PanequeGálvez et al. 2014; Sandbrook 2015). Cheaper parts from Chinese companies and new autopilot systems have made the technology much more accessible, and several initiatives using UAVs for conservation and mapping have been established in Southeast Asia. One of the better known ones is 'Conservation Drones', an initiative established to use drones to monitor forest and wildlife in Sumatra, Indonesia (Koh and Wich 2012).

Early counter-maps often had technical limitations, with corresponding social and political implications. Conventional counter-mapping strategies were based on community sketches in combination with low-resolution satellite images that were becoming freely available, such as Landsat images. The results were often not of a quality that could compete with state spatial planning or cadastral maps, as the underlying images were usually of low quality, sometimes obscured by cloud cover or outdated (Koh and Wich 2012 , 122). This did not necessarily harm the internal functions and empowering effects of counter-mapping. But it did limit the use of the respective maps when the goal was to gain formal recognition by state offices and courts. Attempts to technically improve and professionalize mapping only reinforced the political and social contradictions of counter-mapping outlined above. Interpreting satellite images is a specialized skill, creating the problem of technology and information capture and control by outside organizations or tensions inside the NGOs that were trying to develop such expertise (Fox et al. 2008, 205). High-resolution aerial photographs, which would require less technical expertise to analyze, were generally not available due to their prohibitive cost and, where available, required substantial donor funding.

The use of drones changes several parameters. Maps made using drones are developed from high-resolution photographs stitched together with readily available software on standard laptop equipment. The resolution of the picture is high and thus able to capture objects on the ground with a level of detail that goes beyond that of previous counter-mapping. The high resolution and 'evidential' character of the maps gives them particular appeal as proof or legally reliable information.

The process of producing the photographic map is affordable compared to other technologies and is able to capture a relatively large area in a relatively short period of time. Changes to an area can be captured by drones in shorter time intervals. Drones can be flown from anywhere and can fly over areas that are not accessible on the ground (i.e. difficult terrain, or territory controlled by companies or the state). This makes the tool less controllable in social terms, and this characteristic is intensified by the easy and fast circulation of the digital pictures.

After a mapping flight, images and videos can be directly downloaded onto a laptop, giving instant transparency to village meetings during the mapping project. The resolution is so high that individual houses, trees, swiddens, etc. can be clearly identified, also increasing transparency and the potential to include just about everybody in discussions on how to interpret the maps and what to do with them.

\section{Drone mapping in Tayan}

Although we used drones in three different locations, the most successful case and the most interesting in terms of lessons learnt was in the sub-district Tayan Hilir, less than $100 \mathrm{~km}$ away from the provincial capital Pontianak. The area is affected by the expansion of largescale open-pit mining for bauxite. Bauxite is exported to China to be further processed to obtain aluminum. Bauxite mining not only represents a land grab via the large concessions 
given to the mining corporations but also has immediate detrimental impacts on the ecology of the river and the wetlands connected to it.

Our action research in Tayan was facilitated by leading members of the community. We first accessed the area with the help of academics from the faculty of law at UNTAN University, who had been working on indigenous rights in the area. Through this introduction, the Dayak Customary Council of Tayan supported our action research project. We also teamed up with the Swandiri Institute, an NGO working on land rights and spatial planning. Participation was high. At the first meeting, in a local church in Kecamatan Tayan Hilir, where we introduced the project, 30 community members from Sejotang and Subah villages participated. Ten people volunteered and were selected to join the Citizen Research Group (CRG), representing a cross-section of the community (women and men, old and young, Dayak and Malay).

After conducting the first action research exercises (spatial problem and intervention analysis; change objectives; river transect), the CRG, in conjuncture with the Dayak Customary Council, decided on three interventions. The first was to document the activities of the bauxite mining company, which had extended its activities outside of the concession area, and had drained a lake that had formerly played an important role in the subsistence fishing of Sejotang village. The CRG hoped that the drone could be used to prove that the company was operating illegally and trespassing on land claimed by the two villages (see Figure 1). This was to back up the demand by the Dayak Customary Council for the mining company to restore the area to its natural condition and for residential areas to be taken back out of the concession area. The second intervention was to use drones to map customarilymanaged fruit forests (locally called 'tembawang') that cover several hills surrounding the village, which also function as the water catchment area serving the needs of drinking water for the local community. Here the aim was to use high-resolution images made by the drone to obtain a customary forest title for these forests. The third intervention was to use droneproduced maps as evidence to support the local communities' efforts to challenge the current state-prescribed 'forest' status of their residential and farming areas. With the current 'forest' status, the local community does not have legal rights over the area. The existing land use planning maps were made on the basis of satellite imagery where the small hamlets were not visible. In the process of map-making by the state, the hamlets have literally 'disappeared', resulting in a loss of rights for the villagers to their land. With the high-resolution drone maps, however, residential areas, farming, fruit tree forests and other long-term uses of the land were rendered visible (Figure 1).

The process involved in using drones to produce different counter-maps in Tayan raises interesting points about how the possibilities of new technologies in counter-mapping overcome or perhaps reinforce some of the unintended and problematic consequences sketched out above. Firstly, the postcolonial critique, that the mapping process itself reinforces colonial epistemologies by reproducing territorialized and exclusive maps, was not particularly relevant to the local activists in Tayan. Their whole area had already been territorialized, privatized, leased out to corporations and polluted. The political struggle was not to defend or regain a pre-colonial spatiality of indigenous fluid common property regime. Rather, the activists in the CRG and leaders in the Dayak Customary Council were interested in very concretely using maps to provide evidence of illegal and serious environmental destruction (of the lake), to underline their claim to customary forests versus state forest control, and to legalize their residential areas and activities in these areas by taking out these areas of the state forest definition. None of these mapping activities that were targeted against state territorial control implied a different or new kind of internal 


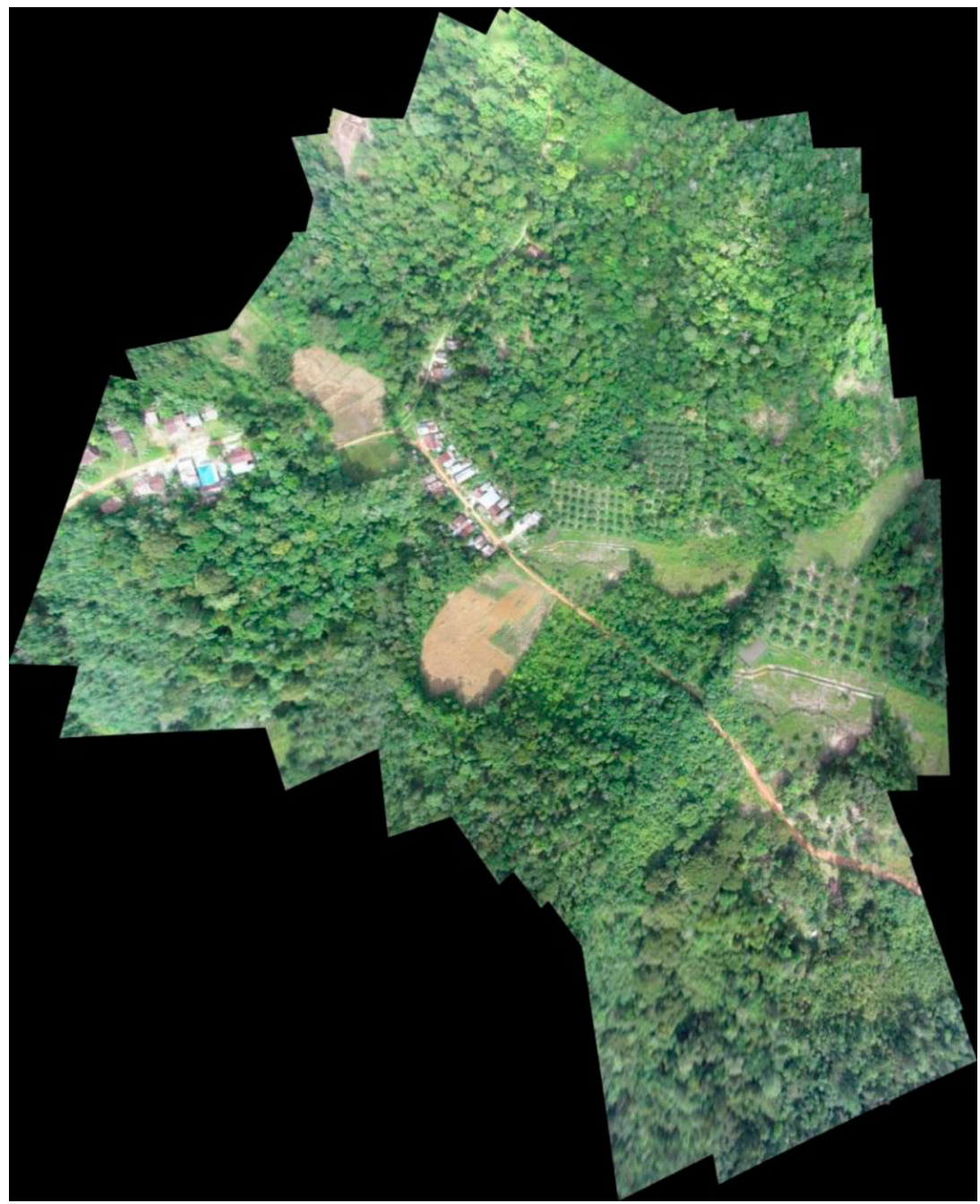

Figure 1. Drone-produced orthophoto showing the Batu Besi Hamlet which is categorized by the state as 'forest' area.

regulation (in customary law) of land and water use rights vis-à-vis the lake or the tembawang forests.

The technical innovation of drones had an immediate impact on the socio-economic and power-related problem of previous counter-mapping, by which the funds and technological expertise needed for geographic information system (GIS)/satellite-based mapping keeps knowledge and power in the hands of an elite group or outside NGOs and experts. In collaboration with the Pontianak-based Swandiri Institute, our action research project set up a drone school in the sub-district in which around 25 people participated. This included Dayaks and Malays, village-level state officials, members of the Dayak Customary Council and a large number of technophile younger men. The principled objective, to distribute the power of drone mapping to as many people as possible, followed the 'three As': acquire data, analyze data and articulate data. The idea was that community activists should learn not only how to fly the drone, but also how to use software to stitch the 
orthophotographs together to create spatially referenced maps, and to use these maps to argue their case in the relevant political setting.

The drone technology proved to be a perfect tool to generate a broad and participatory ownership of the whole process. The drone itself - in contrast to a satellite - has a compelling physical presence. It is fun and exciting, attracts children and others to take a look, and leads to questions, curiosity, and more questions. Then there is the question of the flight path: what do we want to map, and why? This is also perfectly adapted to broad participation. The analysis too, invites discussions and interpretations by everyone, in contrast to the daunting task of analyzing satellite pictures, which can only be done by experts. The images can be downloaded to a laptop very quickly, and the results of the mapping can be made immediately transparent and available. The resolution is so high that anyone can comment on any bit of land-use change that it documents.

The drone school, by training about 25 people from the community, could prove that this is a technology that can be mastered by 'the masses'. The same also goes for the technology needed and the cost of that technology. By assembling the drone out of different second hand pieces, the costs of the drone could be kept to a minimum (see Radjawali and Pye 2017). The software needed to produce the maps from the images is open source. Nowadays, a lot of people have mobile phones which can be used to fly the drones, and at least several people at the village level in Indonesia have a laptop. It is therefore no longer the case that the technology itself represents a knowledge and financial barrier to the control and implementation of this technically superior form of counter-mapping.

The third area of critique, that a given 'community' is not a homogenous group characterized by solidarity and that the mapping process itself is shaped and can reinforce existing power relations and tensions, is still very valid. Although the accessibility of the drone technology can potentially make it easier to be a more egalitarian and inclusive tool, this does not happen automatically. For example, our project and the NGO Swandiri Institute still played an important role in the 'control' of the drone school, access to outside information, political contextualization, networks, etc. At the same time, we were dependent on the cooperation with the Dayak Customary Council, and thereby involuntarily reinforced existing power relations on the local scale. This was particularly evident in the way the drone project reinforced unequal gender relations. Although the drone school did lead to younger and more technophile members of the village playing an active and leading role, and in this way challenged some of the traditional seniority power relations, these youngsters were almost all male. In this way, the introduction of the drone reinforced existing gender roles and empowered men, disempowering women in the process.

\section{Scaling up and some initial victories}

The experience in Tayan is worth thinking through because a relatively small action research intervention led to a full-fledged counter-mapping initiative in the area that continued after the project ended. The involvement of the Swandiri Institute played a crucial role. Rather than a German-run project leaving with the 'results' (perhaps a nicely participatorily produced counter-map?), the cooperation with local NGOs was crucial to ensure that the action research initiated by us developed into a longer term political process. The Swandiri Institute was able to establish an approach they call 'community drones', i.e. a group of mixed NGO activists and local community members performing participatory countermapping using drones. The Swandiri Institute was able to organize financial support from PWYP-Indonesia and the Samdhana Institute (a Bogor-based NGO) to continue the drone mapping of customary forest and land in the area. 
The maps are not an end in themselves but a means to an end, or to several ends. In two of their interventions, the local activists were successful in achieving recognition at the local and regency levels. With the support of the Swandiri Institute and by using political connections of the Dayak Customary Council, the Tayan activists persuaded the spatial planning officials at the Kabupaten to acknowledge the village forests and the residential areas shown on the maps. However, this is as far as it has gone as of now. Only the forestry department has the authority to change the status of 'state forest land' to 'other land use' (ALP) and to customary forest - and the department is notoriously slow and reluctant to do so. The third intervention, the spatial documentation of illegal activities by the mining company, however, led to a whole new dynamic.

On 1 September 2014, one of Dayak Tobag leaders from Tayan gave testimony to the Constitutional Court in Jakarta, using drone-produced orthophotos (e.g. Figure 2). A little background is needed to understand how this came about. In 2009, the Indonesian parliament had passed a new mining law that required mining companies to process ore in Indonesia and to build smelters in their operations in order to do so. This law was challenged by a couple of foreign corporations, who argued that it contradicted the Indonesian Constitution. In the trial, the Court invited NGOs and local communities to testify on the local impacts of mining in order to establish whether the requirement for further processing was necessary or not. This also entailed giving evidence on the social and ecological impacts of mining so that the Court could weigh up the pros and cons of mining for Indonesian society.

Maps that we had jointly produced with the drones were used to support the Dayak Tobag leaders' arguments regarding the detrimental social and ecological effects of mining in the region. The Constitutional Court ruled against the mining corporations in

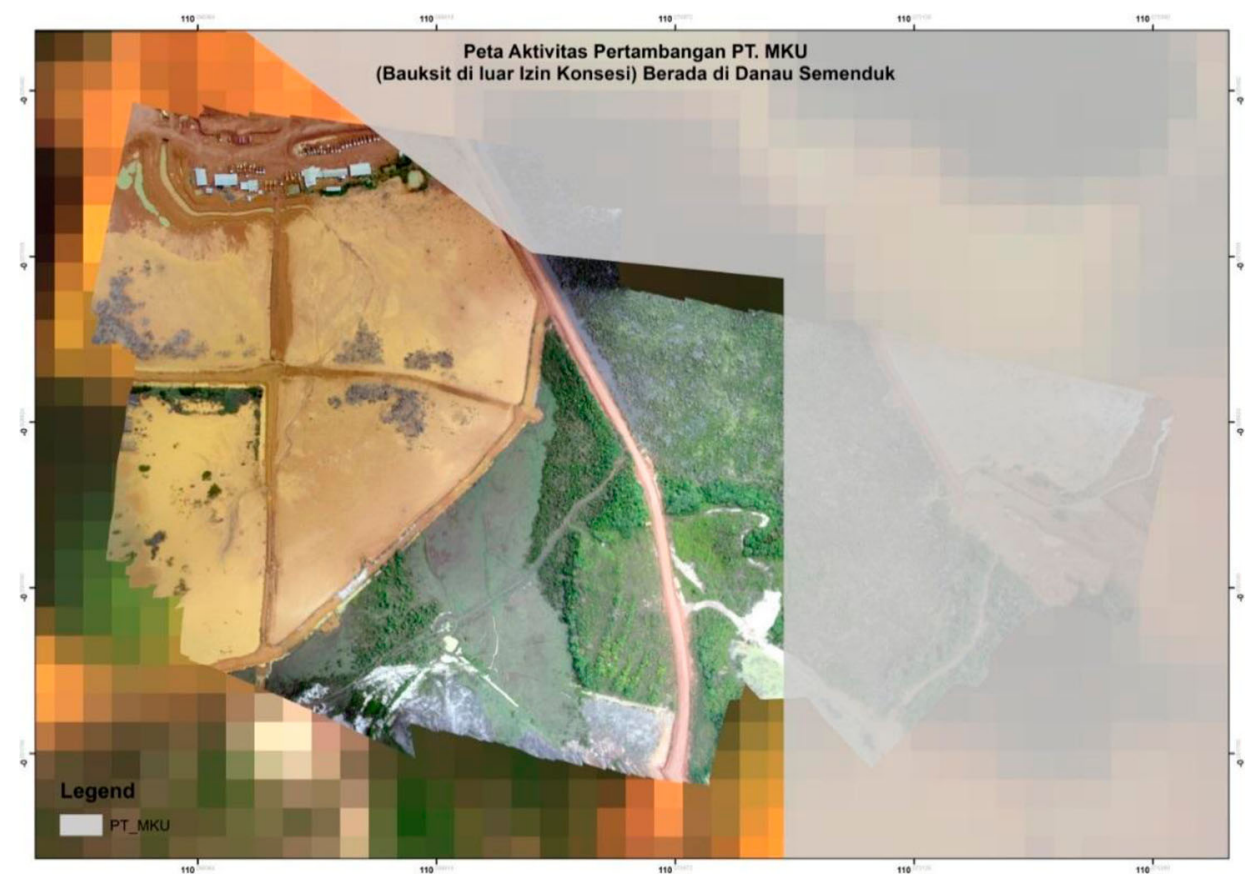

Figure 2. Georeferenced orthophoto taken by drones showing illegal mining activities. The gray shaded area is the official concession area. The area in the left shows the lake that was drained. 
December 2014, upholding the obligation of mining companies to install smelters and to process raw minerals and coal before exporting them. Apart from the substantive matters, civil society organizations view the trial as having set a precedent for the recognition of drone counter-maps as evidence in the Indonesian legal system. Another upshot of this testimony was that the status of allocated mining concessions was reviewed by the Ministry of Energy and Mineral Resources. The drone-map proved beyond doubt that the mining company in Tayan, which had been given a 'clear and clean' status after a previous review, was operating illegally. The Swandiri Institute published a report using drone orthophotos to argue that many mining operations in West Kalimantan violated this 'clear and clean' categorization in many cases (Eyes On The Forest Jaringan Kalimantan Barat 2016). Several mining operations, including the one in Tayan, have now been shut down.

In September 2015, the drone-based counter-mapping helped to secure a third victory when the Provincial Government of West Kalimantan enacted a Provincial Regulation on Spatial Plan Documents (RTRW). Civil society organizations had campaigned and developed a discursive process with the provincial government for several years. More specifically, the Civil Society Coalition for a Just and Sustainable Spatial Plan in West Kalimantan (Koalisi Masyarakat Sipil untuk Tata Ruang yang Adil dan Berkelanjutan) had been disputing the RTRW plan due to its strong bias towards investors and the concession system. In particular, the plan aimed to change the status of over 400,000 ha from forest to APL. At the hearing on the proposed RTRW, the coalition used drone orthophotos produced in Tayan to prove that palm oil had already been established on land with forest status (thus illegally) and could argue that the status change to APL would retrospectively legalize illegal operations.

Again, evidence (including maps made by community drones in Tayan) was helpful in confronting the provincial government with the views of civil society organizations. Some of their demands were incorporated into the new provincial spatial planning legislation, including: (1) recognition of community-managed lands, (2) recognition of customary community rights, and (3) an active involvement of communities in the spatial planning process.

\section{Discussion and conclusion}

The successful development of the community drone concept by the Swandiri Institute in West Kalimantan, as illustrated in these examples, has generated a lot of interest, particularly from organizations working on indigenous issues like AMAN, the Samdhana Institute, Sampan and Lingkar Borneo (two NGOs based in Pontianak, West Kalimantan). Donor organizations like Ford Foundation Indonesia and the Asia Foundation are also interested in this development. Because of the level of interest and the potential use of drones within the new legal framework, the Swandiri Institute as well as Sampan of West Kalimantan organized a series of drone trainings. The Swandiri Institute established a 'drone school' in West Kalimantan, in which civil society organizations and community activists who were interested in learning and using drones for mapping and for advocacy work could join and participate. Another drone school, called 'Sekolah Drone Desa' (Village Drone School), was established by Bogor Agricultural University in early May 2015. The focus is on using drones at the village level to map village areas and to confirm village borders.

The AMAN network is interested in speeding up their participatory mapping using drones, given the fact that drones can map larger areas in a relatively short time and provide high-resolution and geo-referenced orthophotos, and has started organizing training 
of its own. Indonesia's Friends of the Earth network WALHI is also interested in using drones to support their advocacy work. Various members of WALHI have started to use drones (i.e. WALHI Kalimantan Barat, WALHI Kalimantan Tengah). Furthermore, several environmental groups have started to use drones to produce aerial videos of the area where they work, to provide themselves with audio-visual evidence regarding matters of environmental justice.

Finally, the Indonesian branch of PWYP-Indonesia has also begun using drones to support its work, which focuses on transparency issues in the extractive industries sector. PWYP-Indonesia has supported the Swandiri Institute to conduct research related to the Extractive Industries Transparency Initiative (EITI). Using drones combined with spatial analysis and open web-GIS application as well as open-source GIS application (Qgis), the Swandiri Institute has conducted research which explored further spatial transparency issues. Overlapping concessions are plotted in a GIS application and supported by highresolution orthophotos made by drones. This has been a useful tool to monitor illegal activities as well as the real condition of mining sites in West Kalimantan.

This also has been a useful approach in advocating for local community members whose lands are encroached and grabbed. Furthermore, this tool has also contributed to the mapping of all concessions in West Kalimantan including overlaps with other concessions or with other types of land use (i.e. forest, community-managed land), which can now be accessed online. Users can zoom in on pictures made by drones and can access precise data on specific areas. This has been a very helpful tool for NGOs and civil society organizations to build their arguments and action plans for resisting ongoing land encroachments and land acquisitions.

These interlinked institutional and technical developments indicate that drone technology is currently revolutionizing the counter-mapping movement in Indonesia. Can drones be used for emancipatory purposes or, asked differently, is there a road from reconnaissance to recognition? We maintain that there are quite a number of occasions on which drones can provide pictures that may be highly useful in political struggles around territorial claims and natural resource exploitation. It seems worth exploring in the future in more detail where the specific problems with using drones are situated and which negative or politically unwanted effects they may have that are not common in other counter-mapping techniques.

The appropriation of the drone technology by community activists was rather uncomplicated in our case and may generally have the potential to improve the situation with regard to inclusion, transparency and empowerment. The Swandiri Institute's experience of establishing a 'community drones' approach in Tayan, in which community members were actively involved, shows that the drone technology is more easily accessible than former technically ambitious counter-mapping technologies. Nowadays, younger members of local communities are computer literate and they seem particularly attracted to the drone as technical object - implying a shift from the typical elderly authorities and knowledge brokers to technophile young activists (albeit with a comparable gender bias).

The technology can be very empowering in a direct way. The sense of power and achievement when community members themselves fly the drone is substantial. Even greater is the empowerment impact that comes with the knowledge that these images are of higher quality than many concession maps and that they have now been acknowledged by the courts.

The obvious downside of this fungible digital character is that it can be easily appropriated by other actors, and its in-built tendency of quite literally 'rendering technical' all kinds of conflicts in a much faster and more efficient way than earlier kinds of 
Table 1. Contrasting classical counter-mapping and drone counter-mapping.

\begin{tabular}{|c|c|c|}
\hline Typical features & Classical counter-mapping & Drone counter-mapping \\
\hline Visualization & Sketch, satellite images & Orthophoto \\
\hline Media & Paper, copies & Digital camera, laptop \\
\hline $\begin{array}{l}\text { Counter-mapping } \\
\text { mode }\end{array}$ & Objection, political claim & Documentation, legal evidence \\
\hline Production & $\begin{array}{l}\text { Technically 'bottom up', } \\
\text { grounded, contextual }\end{array}$ & $\begin{array}{l}\text { Technically 'top down', autonomous, } \\
\text { independent }\end{array}$ \\
\hline Distril & Slow, academic, political & Fast, popular, pluri-directional \\
\hline $\begin{array}{l}\text { Key actor(s) in } \\
\text { collaboration }\end{array}$ & Informant, knowledge authority & Activist, technophile youth \\
\hline Epistemic foundation & Diffe & $\mathrm{Te}$ \\
\hline Power traps & Affiliation, exposure, paternalism & Appropriability, rendering technical \\
\hline
\end{tabular}

counter-mapping. This may pave the way for technocratic solutions of deep-seated political conflicts.

The problems of hierarchy and affiliation may be less pronounced, but we have nevertheless encountered them and relied on 'customary leaders' in different phases of our project. Table 1 contrasts the typical, idealized features of classical counter-mapping on one side and drone counter-mapping on the other in an attempt to highlight potential changes brought about by the new tool.

Rather unsurprisingly, drones are not a magic wand that can conjure away hierarchies and power structures at the local level or in wider society. Thus, we were unable to use drones in those areas where local elites were in cahoots with plantation and mining companies and controlled traditional institutions such as customary councils, and where opposition was marginalized (see Radjawali and Pye 2017). And in Tayan, where we had the backing of the customary council, hierarchical gender relations in the village, power dynamics, and territorial disputes between different villages were replicated in the mapping process. Furthermore, civil society organizations are still necessary for some funding, and also for training and advocacy.

Still, the concept and use of community drones is currently spreading like wildfire in Indonesia. This is because the technological revolution has shown its potential - together with campaigning and political pressure - to force through the recognition of community counter-maps in the spatial planning process. This is happening at the same time that the political opportunity of reclaiming millions of hectares of customary forests, and of initiating the active involvement of people at the village level in spatial planning processes, is there to grasp. In this context, community drones for counter-mapping will hardly become a 'science of the masses', to borrow Peluso's term, but they may become a widely accessible tool with an impressive reach, adding to the 'weapons of the weak' (Scott 1985) against land grabbing.

\section{Contributions}

All authors developed this work jointly in the course of the above-mentioned research project. The first author (IR) carried out most of the field work and is responsible for the practical work with the drones and according collaborations. The second author (OP) developed the conceptual basis for our joint participatory research and also drafted a first version of the text. The third author (MF) was mainly responsible for relating our research to the debates around counter-mapping. 


\section{Acknowledgements}

We thank the DFG for supporting our research 'Connecting the urban and the rural: a political ecology of the Kapuas River (Kalimantan, Indonesia)' (GZ PY 76/3-1 and FL 392/3-1). Thanks also to the Swandiri Institute and Lembaga Gemawan for taking further steps and for putting the idea of counter-mapping drones into action.

\section{Disclosure statement}

No potential conflict of interest was reported by the authors.

\section{Funding}

This work was supported by the German Research Foundation [grant number GZ PY 76/3-1 and FL 392/3-1].

\section{References}

Agrawal, A. 1995. Dismantling the divide between indigenous and scientific knowledge. Development and Change 26: 413-39.

Eyes On The Forest Jaringan Kalimantan Barat. 2016. Berlindung di balik selimut CnC: Laporan monitoring IUP Minerba di Kalimantan Barat.

Fox, J., K. Suryanata, P. Hershock, and A.H. Pramono. 2008. Mapping boundaries, shifting power: The socio-ethical dimensions of particpatory mapping. In Contentious geographies. environmental knowledge, meaning, scale, ed. M.K. Goodman, M.T. Boykoff, and K.T. Evered, 20317. Aldershot: Ashgate Publishing.

Hanafi, I. 2015. Satu Peta Untuk Semua. http://www.brwa.or.id/articles/read/165 (accessed May, 2015).

Harley, J.B. 1988. Maps, knowledge and power. In The iconography of landscape, ed. D. Cosgrove and S. Daniels, 277-312. New York: Cambridge University Press.

Honneth, A. 1996. The struggle for recognition: The moral grammar of social conflicts. Cambridge: MIT Press.

JKPP. 2009. Menuju Demokratisasi Pemetaan: Refleksi Gerakan Pemetaan Partisipatif di Indonesia. Bogor.

Koh, L.P., and S.A. Wich. 2012. Dawn of drone ecology: Low-cost autonomous aerial vehicles for conservation. Tropical Conservation Science 5, no. 2: 121-32.

Lembaga Gemawan, Indonesia Corruption Watch and Koalisi Masyarakat Sipil Untuk Tata Ruang yang Adil dan Berkelanjutan. 2013. Public Review: Rancangan Peraturan Daerah Rencana Tata Ruang Wilayah Provinsi Kalimantan Barat.

Li, T. M. 2000. Articulating indigenous identity in Indonesia: Resource politics and the tribal slot. Comparative Studies in Society and History 42, no. 01: 149-79.

Louis, R. P., J. T. Johnson, and A.H. Pramono. 2012. Introduction: Indigenous cartographies and counter-mapping. Cartographica: The International Journal for Geographic Information and Geovisualization 47, no. 2, 77-9.

Momberg, F. 1994. Participatory tools for community forest profiling and zonation of conservation areas: Experiences from the Kayang-Mentarang Nature Reserve, East Kalimantan, Indonesia. Paper presented at the Borneo Research Council Third Biennial International Conference, Pentavank, July 1-14.

Paneque-Gálvez, J., M.K. McCall, B.M. Napoletano, S.A. Wich and L. P. Koh. 2014. Small drones for community-based forest monitoring: An assessment of their feasibility and potential in tropical areas. Forests 5, no. 6: 1481-507.

Palmer, M. 2012. Theorizing Indigital Geographic Information Networks. Cartographica 47, no. 2: $80-9$.

Parker, B. 2006. Constructing community through maps? Power and praxis in community mapping*. The Professional Geographer 58, no. 4: 470-84. doi:10.1111/j.1467-9272.2006.00583.x

Peluso, N.L. 1995. Whose woods are these? Counter-mapping forest territories in Kalimantan, Indonesia. Antipode 27, no. 4: 383-406. 
Pramono, A.H., I. Natalia and Y. Janting. 2006. Ten years after: Counter-mapping and the Dayak lands in West Kalimantan, Indonesia (Unpublished report).

Pye, O., I. Radjawali and Julia. 2017. Land grabs and the river. Canadian Journal of Development Studies. Special Issue on Climate change policies, resource grabbing and conflict: perspectives from Southeast Asia (submitted).

Rachman, N. F. and D. Yanuardy. 2014. MP3EI. Master Plan Percepatan dan Perluasan Krisis Sosial-Ekologis Indonesia. Bogor: Sajogyo Institute.

Radjawali, I. and O. Pye. 2017. Drones for justice: Inclusive technology and river-related action research along The Kapuas. Geographica Helvetica, Special Issue (in press).

Sandbrook, C. 2015. The social implications of using drones for biodiversity conservation. Ambio 44, no. 4: 636-47.

Scott, J. 1985. Weapons of the weak: Everyday forms of peasant resistance. New Haven and London: Yale University Press.

Scott, J. 1998. Seeing like a state. New Haven and London: Yale University Press.

Sirait, M., S. Prasodjo, N. Podger, A. Flavell, and J. Fox. 1994. Mapping Customary land in East Kalimantan, Indonesia. Ambio 23, no. 7: 411-17.

Swandiri Institute. 2014. Towards spatial transparency: Rapid socio-spatial assessment of extractive industries in West Kalimantan, Indonesia. The Extractive Industries Transparency Initiative Final Report.

Vermeylen, S. G. Davies and D. Van Der Horst. 2012. Deconstructing the Conservancy Map: Hxaro, N!ore, and Rhizomes in the Kalahari. Cartographica 47(2): 121-134.

Wainwright, J. and J. Bryan 2009. Cartography, territory, property: Postcolonial reflections on indigenous counter-mapping in Nicaragua and Belize. cultural geographies 16, no. 2: 153-78.

Wood, D. [with J. Fels]. 1992. The power of maps. New York: Guilford Press.

Michael Flitner is a professor of human geography at the University of Bremen, Germany, Chair of the Sustainability Research Centre (artec), and a co-founder of the Bremen NatureCultures Lab. He received his $\mathrm{PhD}$ from Hamburg University in 1995 with a work on German plant collecting missions during the twentieth century in their changing political contexts. His habilitation at Freiburg University on transboundary conflicts around airport noise won the Karl William Kapp Award for Ecological Economics in 2005. His research broadly explores issues of political ecology, environmental justice, and the social and cultural dimensions of urban and coastal natures. Email: mflitner@uni-bremen.de

Oliver Pye is a lecturer in Southeast Asian Studies at Bonn University, with a research focus on political ecology and social movements. Together with Michael Flitner, he led the research project 'Connecting the urban and the rural: a political ecology of the Kapuas River (Kalimantan, Indonesia)' (funded by the DFG), which was the basis for this contribution. He is currently working on the relation between labor and nature in palm oil Global Production Networks. Recent publications include The palm oil controversy in Southeast Asia. A transnational perspective (2012) and A political ecology of agrofuels (2015, co-edited). Email: oliver.pye@uni-bonn.de

Irendra Radjawali is a scholar activist associated with the Department of Southeast Asian Studies, Bonn University. He was a principal researcher on the project 'Connecting the urban and the rural: a political ecology of the Kapuas River (Kalimantan, Indonesia)' (2011-2015, funded by the DFG) and introduced the drone as a component of the action research. He is currently training hundreds of activists in Indonesia and globally in the construction and use of drones for counter-mapping. Email: radja@hotmail.com 